\title{
First report of postharvest root rot caused by Rhizopus oryzae on Codonopsis lanceolata
}

\author{
Ji-Hyun Park • Sung-Eun Cho • Byung-Sup Kim • \\ Hyeon-Dong Shin
}

Received: 3 March 2014 / Accepted: 17 April 2014 / Published online: 28 April 2014

(C) Australasian Plant Pathology Society Inc. 2014

\begin{abstract}
Postharvest root rot of Codonopsis lanceolata was found at storage piles in a market in Seoul, Korea, 2012. Based on the morphological characteristics and molecular analyses of the ITS rDNA and D1/D2 region of the LSU, the causal fungus was identified as Rhizopus oryzae. This is the first report of Rhizopus-associated root rot on Codonopsis lanceolata.
\end{abstract}

Keywords Postharvest root rot · Codonopsis lanceolata . Rhizopus oryzae $\cdot$ ITS sequence $\cdot \mathrm{D} 1 / \mathrm{D} 2$ region of the LSU

Codonopsis lanceolata, native to East Asia, is an important medicinal root crop in Korea, second only to ginseng. This plant has long been used for therapeutic purposes as a traditional fork medicine. The root extract of $C$. lanceolata has pharmacological properties including anti-obesity, antiinflammatory activity and anti-tumor effects ( $\mathrm{Li}$ et al. 2007; Cho et al. 2011; Choi et al. 2013). It is widely cultivated, with 2 or 3 year old roots harvested for eating whereas 6 year old roots are highly valued and mostly used for medicinal purposes. Recently, these medicinal effects have led to its high demand as a good source of functional foods for improving physical constitution. As of 2010 , production was $7,766 \mathrm{M} / \mathrm{T}$ from a cultivation area of 1,536 ha in Korea, which is increasing annually (Park et al. 2011).

Rhizopus oryzae, currently synonymous with Rhizopus arrhizus, is well known worldwide as a severe postharvest pathogen causing serious problems in successful storage and

J.-H. Park $\cdot$ S.-E. Cho $\cdot$ H.-D. Shin $(\bowtie)$

Division of Environmental Science and Ecological Engineering,

Korea University, Seoul 136-701, Korea

e-mail: hdshin@korea.ac.kr

B.-S. Kim

Department of Plant Science, Gangneung-Wonju National

University, Gangneung 210-702, Korea marketing of products (Amadioha 1996, 2001). In Korea, postharvest rot cause by $R$. oryzae has been recorded on various fruits and vegetables including banana, apple, and sweet potato (Kwon et al. 2011, 2012a, b).

In May 2012, a small pile of rotted C. lanceolata roots was observed in a market in Seoul. Symptoms usually began in wounded or damaged parts of the root. Infected roots appeared water-soaked, and the root epidermis was easily sloughed off, showing reddish brown, discoloured tissues. In humid condition, lesions were covered with white mycelial tufts (Fig. 1a-b). As decay progressed, sporangiophores with dark pigmented sporangia grew out through infected tissues.

To perform the morphological observation, the fungal structures were detached from the infected lesions using watchmaker's forceps and water-mounted on glass slides. Each structure was examined in bright fieldand differential interference contrast light microscopy with Olympus BX51 microscope (Olympus, Tokyo, Japan) and photographed using a Zeiss AX10 microscope equipped with AxioCam MRc5 (Carl Zeiss, Göttingen, Germany). At least 30 measurements were made for each structure. Voucher specimens were housed in the Korea University Herbarium (KUS). The fungus associated with the symptoms was isolated on potato dextrose agar (PDA). An isolate obtained from KUS-F26796 was deposited in the Korean Agricultural Culture Collection (Accession No. KACC47222) and used for pathogenicity testing and molecular analysis.

The colonies were at first white and cottony, then became grey to black with the appearance of sporangia (Fig. 1g). Sporangiophores were mostly erect, unbranched, subhyaline to brown, singly or in groups, and 180 to $1,500 \mu \mathrm{m}$ long, 10 to $15 \mu \mathrm{m}$ wide (Fig. 1c). Sporangia were globose to subglobose, greyish brown to black, and 65 to $200 \mu \mathrm{m}$ in diameter (Fig. 1d-e). Columella were subglobose to ovoid, subhyaline 
Fig. 1 Root rot of Codonopsis lanceolata infected with Rhizopus oryzae. (a) Infection of the root covered with white mycelial tufts. (b) Longitudinal section of infected root showing watersoaked symptoms (c)

Conidiophores with rhizoids. (d) Conidiophores with sporangia. (e) Columellum with numerous sporangiospores. (f) Sporangiospores. (g) One-weekold colony of $R$. oryzae growing on a potato dextrose agar. Scale bars $=200 \mu \mathrm{m}$ for $\mathrm{c}-\mathrm{d}, 100 \mu \mathrm{m}$ for e and $10 \mu \mathrm{m}$ for $\mathrm{f}$
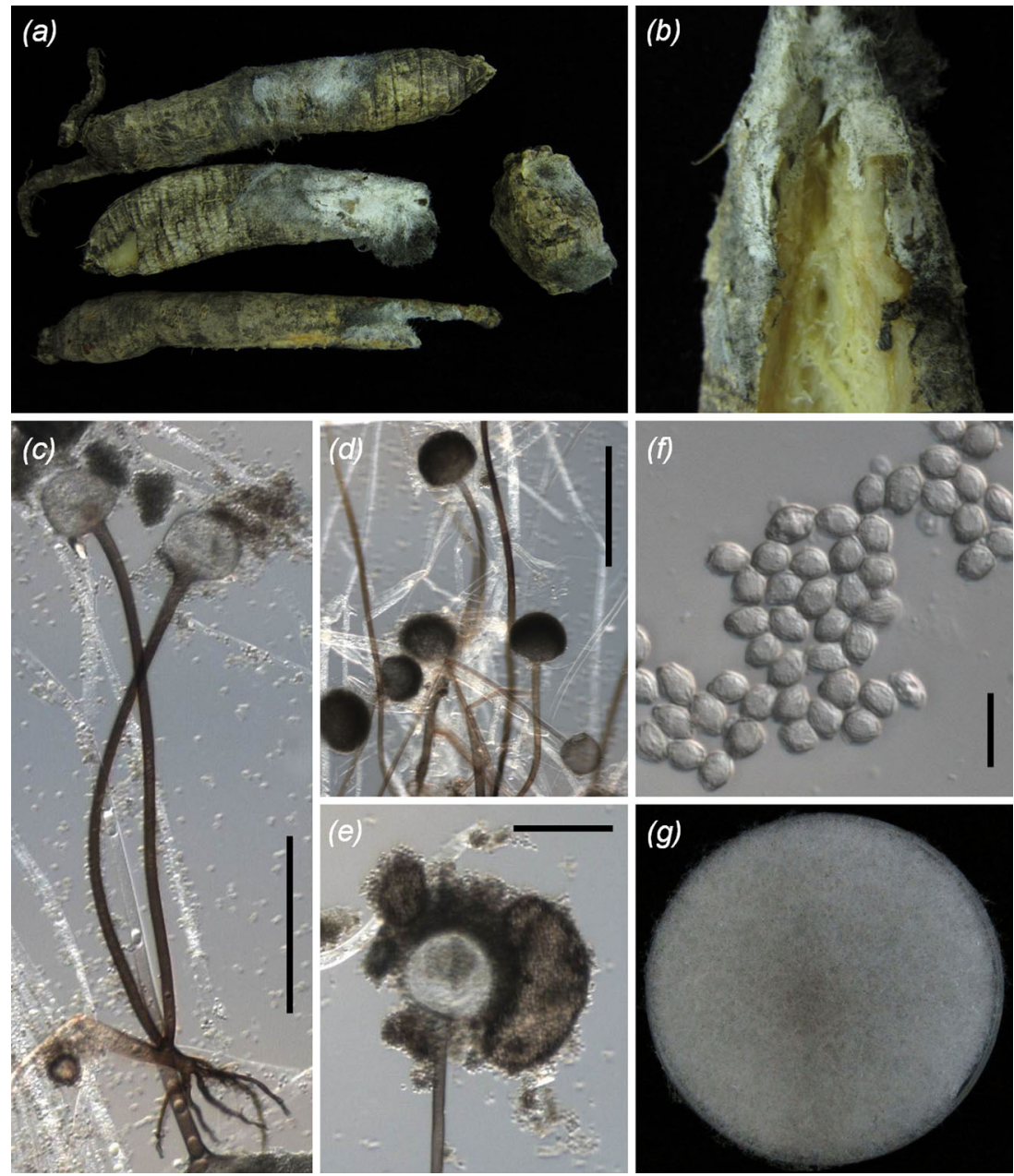

to greyish brown, and 35 to $100 \times 50$ to $120 \mu \mathrm{m}$. Sporangiospores were ovoid, angular, striate, pale greyish to brown, and 5 to $8 \times 3$ to $5 \mu \mathrm{m}$ (Fig. $1 \mathrm{f}$ ). Chlamydospores and zygospores were not observed. The fungus was identified as Rhizopus oryzae based on the morphological characteristics and growth temperature (Liou et al. 2007).

To confirm the identity of the causal fungus, genomic DNA was extracted with DNeasy Plant Mini Kits (Qiagen Inc., Valencia, CA). The internal transcribed spacer (ITS) region of rDNA and the D1/D2 region of the large subunit (LSU) were amplified with primers ITS1/ITS4 (White et al. 1990) and primers NL1/LR3 (O’Donnell 1993) and sequenced. The resulting 588 bp ITS sequences and 655 bp D1/D2 sequences were deposited in GenBank under accession numbers KF218955 and KF218956. A GenBank BLAST search with the present data revealed that the ITS sequences showed $100 \%$ similarity with that of R. oryzae (JX120700) and D1/D2 sequences also showed $100 \%$ identity with that of $R$. oryzae (JQ745263).

A conidial suspension $\left(2 \times 10^{6}\right.$ conidia/ml $)$ was sprayed over five three-year-old roots of $C$. lanceolata wounded with a fine needle and kept in plastic containers $\left(25{ }^{\circ} \mathrm{C}\right.$ and $\left.100 \% \mathrm{RH}\right)$. Five roots of the same age sprayed with sterile water served as controls. After 3 days, typical root rot symptoms, identical to the ones observed in the market, developed on the inoculated roots. No symptoms were observed on controls. Rhizopus oryzae was reisolated from the lesions of inoculated roots, fulfilling Koch's postulates.

Root rots of $C$. lanceolata caused by Fusarium oxysporum and Sclerotium rolfsii (=Athelia rolfsii) in fields are known to occur in Korea (Kim et al. 1998; Farr and Rossman 2014). Such pathogens can be associated with postharvest root rots. However, no Rhizopusassociated root rots were reported. To our knowledge, this is the first report of $R$. oryzae as a postharvest pathogen on $C$. lanceolata roots globally as well as in Korea. Our observations in storage rooms and in markets suggest that preventing wounds on roots as well as maintaining good hygiene during handling might be the main strategies for controlling this postharvest root rot.

Acknowledgments This work was financially supported by the National Institute of Biological Resources (NIBR) of Ministry of Environment, KOREA (1834-302, Graduate Program for the Undiscovered Taxa of Korea). 


\section{References}

Amadioha AC (1996) Control of storage rot of potato caused by Rhizopus oryzae. Int J Pest Manag 52:311-314

Amadioha AC (2001) Fungitoxic effects of some leaf extracts against Rhizopus oryzae causing tuber rot of potato. Arch Phytopathol Plant Protect 33:499-507

Cho YR, Kim SH, Yoon HJ, Hong SY, Ko HY, Park EH, Kim MD, Seo DW (2011) Anti-tumor effects of Codonopsis lanceolata extracts on human lung and ovarian cancer. Food Eng Prog 15:1-5

Choi HK, Won EK, Jang YP, Choung SY (2013) Antiobesity effect of Codonopsis lanceolata in high -calorie/high-fat-diet-induced obese rats. Evid Based Complement Alternat Med pp 210297

Farr DF, Rossman AY (2014) Fungal databases, systematic mycology and microbiology laboratory, ARS, USDA. Retrieved 26 Feb 2014, from $\mathrm{http}: / /$ nt.ars-grin.gov/fungaldatabases

Kim JH, Kim JS (1998) Incidence of diseases in Codonopsis lanceolata with different cultivation method. Korean J Plant Pathol 14:676-681

Kwon JH, Kim J, Kim WI (2011) First report of Rhizopus oryzae as a postharvest pathogen of apple in Korea. Mycobiology 39:140-142
Kwon JH, Kim MK, Choi O, Kim J (2012a) First report of Rhizopus oryzae as a postharvest pathogen of sweet potato in Korea. Plant Pathol J 28:114

Kwon JH, Ryu JS, Chi TTP, Shen SS, Choi O (2012b) Soft rot of Rhizopus oryzae as a postharvest pathogen of banana fruit in Korea. Mycobiology 40:214-216

Li JP, Liang ZM, Yuan Z (2007) Triterpenoid saponins and antiinflammatory activity of Codonopsis lanceolata. Pharmazie 62: 463-466

Liou GY, Chen SR, Wei YH, Lee FL, Fu HM, Yuan GF, Stalpers JA (2007) Polyphasic approach to the taxonomy of the Rhizopus stolonifer group. Mycol Res 111:196-203

O’Donnell K (1993) Fusarium and its near relatives. In: Reynolds DR, Taylor JW (eds) The fungal holomorph: mitotic, meiotic and pleomorphic speciation in fungal systematics. CAB International, Wallingford, pp 225-233

Park CB, Ahn YS, Kim YG, Park CG, Ahn TJ, Kang YK (2011) Simple guide to Codonopsis lanceolata cultivation. Rural Develop Administ, Suwon

White TJ, Bruns T, Lee S, Taylor JW (1990) Amplification and direct sequencing of fungal ribosomal RNA genes for phylogenetics. In: Innis MA, Gelfand DH, Sninsky JJ, White TJ (eds) PCR protocols: a guide to methods and applications. Academic, San Diego, pp 315-322 